\title{
Sources and Abbreviations
}

In reconstructing the ritual environments of the Roman and Sasanian courts and their interaction, this project analyzes a broad archive of texts, structures, objects, and images; however, the two fields of Roman/Byzantine studies and Middle Iranian studies have arrived at conflicting approaches to the use of textual material, and in order to carry out a cross-cultural and crossdisciplinary project, these approaches have had to be reconciled. At the end of the last century, Philippe Gignoux advocated a hierarchy of sources that the field of Middle Iranian studies, and this project, generally accept: primarydocuments written in the languages of, and at the same time as, the Sasanian empire; secondary-documents in the same languages but post-Sasanian; tertiary-documents in all other languages (including Greek and Latin texts from the Roman empire). Rika Gyselen expanded Gignoux's approach to include visual and archaeological material: unquestionably contemporary and authentic material such as rock reliefs, coins, archaeologically derived artifacts, and seals form the primary sources, and objects such as silver plate and silk, which lack provenance or come from post-Sasanian manufacture, form the secondary and tertiary sources. Conclusions relying only on secondary and tertiary documents should not be the basis for specific or fundamental claims and should always defer to primary sources when possible.

By necessity, this approach must be modified to deal with questions of

See P. Gignoux, "Problèmes de distinction et de priorité des sources," in Prolegomena to the Sources on the History of Pre-Islamic Central Asia, ed. J. Harmatta (Budapest: Akadémiai Kiadó, 1979), 137-41; id., "Pour une nouvelle histoire de l'Iran sasanide," in Middle Iranian Studies, ed. W. Skalmowski and A. van Tongerloo, Orientalia Lovaniensia Analecta 16 (Leuven: Peeters, 1984), 253-62. For consideration of seals as a primary source, see R. Gyselen, "La désignation territoriale des quatre Spāhbed de l'empire sassanide," StudIr 30 (2001): 137-41. 
cross-cultural (and cross-disciplinary) interaction. My methodological goal has been to find a middle ground between stringent Middle-Iranian scholarship, which would discount the Roman and Byzantine scholarship entirely, because it relies on non-Sasanian sources, and Roman and Byzantine studies' over-privileging of Greek and Latin textual sources when dealing with the Sasanian empire, all while integrating visual and archaeological evidence on an equal footing with textual evidence. Thus I do not hesitate to consider "tertiary" textual or visual evidence, but classify the strength of the conclusions one can draw from it according to this amended hierarchy of sources.

Conventions and abbreviations for all Iranian material conform as far as possible to those used by Encyclopaedia Iranica (EIr). Corresponding to EIr, the names of Sasanian kings of kings are in their New Persian, rather than Middle Persian, form (Šāpūr for Šābuhr, Bahrām for Wahrām, etc.). The transliteration system for New Persian and Arabic is that jointly adopted by Encyclopaedia Iranica and the Corpus Inscriptionum Iranicarum. Pahlavi material follows D. N. MacKenzie's Concise Pahlavi Dictionary. Abbreviations for Greek and Latin authors conform to those of the Oxford Classical Dictionary first; then, for sources not covered in the OCD, the conventions (though not necessarily the editions) used in the Oxford Dictionary of Byzantium $(O D B)$. For modern scholarly material, I follow the abbreviations in Encyclopaedia Iranica and suggested by Dumbarton Oaks (the latter are available in pdf format at doaks.org). Abbreviations not included in these lists or needing clarification I include below. All translations in the text are my own unless indicated.

\section{AchHist}

$\mathrm{AcOr}$

ActIr

$B A I$

Bal'́ami, Tārik

Bundahišn

CambHistIr

EI

EIr

\section{Achaemenid History.}

Acta Orientalia.

Acta Iranica.

Bulletin of the Asia Institute.

Tāriǩ-e Bal'amī. Edited by M. T. Bahār. Tehran: Edāraye Koll-e Negāreš-e Wezārat-e Farhang, 1341/1962.

Bundahišn. Edited by B. T. Anklesaria. Bombay: British India Press, Byculla, 1908.

Cambridge History of Iran.

The Encyclopaedia of Islam. New ed. 13 vols. Leiden: Brill, 1960-2009.

Encyclopaedia Iranica. Edited by E. Yarshater. London and Costa Mesa, Calif.: Mazda Publishers, 1982-. www .iranica.com. 
Hamza

IrAnt

IrDenk

Jāḥiż

KKZ

LTUR

$\operatorname{Mas}^{\mathrm{c}} \mathrm{u} \mathrm{d} \overline{\mathrm{i}}$, Murūj

Barbier

MedAnt

NPEA

NPi

Perses sassanides

Persia e Bisanzio

Skjærvø, Paikuli

ŠKZ

$\breve{S} N$
Hamza al-Iṣfahānī. "The Annals of Hamzah alIșfahānī." Translated by U. M. Daupota. Journal of the K. R. Cama Oriental Institute 21 (1932): 58-120.

Iranica Antiqua.

Iranische Denkmäler. Berlin: Dietrich Reimer Verlag forthe Deutsches Archäologisches Institut, Teheran, 1932-.

Pseudo-al-Jāhiż. Le livre de la couronne. Translated by C. Pellat. Paris: Les Belles Lettres, 1954.

Kerdīr, Ka ba-ye Zardošt inscription.

Lexicon Topographicum Urbis Romae. Edited by E. M. Steinby. Rome: Quasar, 1993-.

al-Mas'ūìi. Murūj al-dahab. Translated by C. de Meynard. In Les Prairies d'Or, vol. 4. Paris: L'Imprimerie Impériale, 1865.

Mediterraneo Antico.

Der neue Pauly: Enzyklopädie der Antike. Edited by H. Cancik und H. Schneider. Stuttgart: J. B. Metzler, 1996-2003.

Narseh, Paikuli inscription.

Les Perses sassanides: Fastes d'un empire oublié (224-642), Musée des arts de l'Asie de la ville de Paris, 15 septembre-3o décembre 2006. Paris: Paris Musées; Suilly-la-Tour: Éditions Findakly, 2006.

Convengo Internazionale La Persia e Bisanzio (Roma: 14-18 ottobre 2002). Atti dei Convengi Lincei 201. Rome: Accademia Nazionale dei Lincei, 2004. The Sassanian Inscription of Paikuli, pt. 3.1. Restored text and translation by Prods O. Skjærvø. Wiesbaden: Reichert, 1983.

Šāpūr I, Ka'ba-ye Zardošt inscription = Die dreisprachige Inschrift Šäbuhrs I. an der Kacba-i Zardušt ( $\breve{K} K Z$ ). Edited and translated by P. Huyse. Corpus Inscriptionum Iranicarum 3.1. London: School of Oriental and African Studies, 1999.

Ferdowsī. Šāhnāma = Shax-nāme. Edited by A. E. Bertels. 9 vols. Moscow: Izd-vo Vostochnoi Lit-ry, 1960-71. 
Ta a ālebī, Gorar

des

Zamyād Yašt
Gorar aǩbār molūk al-fors [of Táālebīšs]. Edited and translated by H. Zotenberg. In Histoire des rois Perses. Paris: Imprimerie Nationale, 1900.

Zamyād Yasht: Yasht 19 of the Younger Avesta: Text, Translation, Commentary. Edited by H. Humbach and P. R. Ichaporia. Wiesbaden: Harrassowitz, 1998. 